\title{
Halal Food Certification: Case of Malaysian SME Entrepreneurs
}

\author{
Mohani Abdul, Hashanah Ismail, Mazlina Mustapha \\ Universiti Putra Malaysia, Selangor, Malaysia
}

\begin{abstract}
This paper reports on 108 Malaysian SME entrepreneurs' perceptions towards Halal Food Certification (HFC) in Malaysia along four dimensions of market share and market competitiveness, government support and monitoring, information dissemination and rigor of certification process using a structured questionnaires distributed during MIHAS 2011. Based on their responses, the study finds that HFC is important to promote customers' confidence, trust, and satisfaction but they were of the opinion that the contents of information were insufficient. Respondents ranked certification process as tedious and stringent hence needs to be improved. They were dissatisfied with the information dissemination on halal hub. Hence the government needs to improve its support and monitoring system. The study also indicates that respondents who have attended entrepreneurship courses, have ventured into international markets, have obtained Halal Certification for their food products and attained at least a bachelor degree level of education have significant different responses towards the HFCs.

Keywords: perceptions, small medium enterprises (SMEs), Halal Food Certification (HFC), market share and market competitiveness, government support and monitoring, information dissemination, rigor of certification process
\end{abstract}

\section{Introduction}

Small and medium enterprises (SMEs) are not only recognized as the backbone of a country's economy, but they also serve as a catalyst to promote a balanced and sustainable growth to the country's gross national product. In Malaysia, SMEs are an important segment of the economy and represents $99.2 \%$ of the total business establishments in Malaysia. These establishments contribute to 31.4\% to the country's GDP, 56.4\% to employment and account for 19\% of Malaysian exports (Thut \& Chang, 2010). Of the total number of enterprises in Malaysia, 12\% are involved in the food and beverage industry, which accounts for about $9 \%$ of the overall contribution of the manufacturing sector to Gross Domestic Product (GDP) and the processed food and beverage were also exported to more than 80 countries (FMM-MATRADE Industry Directory, 2010).

Food is a basic necessity for all mankind. As a Muslim country where Islam is the official religion, every facet of a Muslim's life in Malaysia is guided by the tenets of Islam including what food is appropriate for consumption without jeopardizing a Muslim's faith. Since food is produced by third parties unknown in identity to consumers both Muslim and non-Muslim, there is a need for assurance to the former that food to be selected and consumed meets the Islamic tenet of "Halal" or fit for consumption. Halal is a credence quality

Mohani Abdul, Ph.D., Faculty of Economics and Management, Universiti Putra Malaysia.

Hashanah Ismail, Faculty of Economics and Management, Universiti Putra Malaysia.

Mazlina Mustapha, Ph.D., Faculty of Economics and Management, Universiti Putra Malaysia.

Correspondence concerning this article should be addressed to Mohani Abdul, Faculty of Economics and Management, Universiti Putra Malaysia. E-mail: mohani3242@gmail.com. 
attribute, i.e., a product characteristic that cannot be evaluated or ascertained by the individual consumer, even upon or after consuming the goods (Darby \& Karni, 1973; Grunert, 2005). However, there is neither a worldwide authority on halal nor is there a consistent "Halal" trademark with over 15 halal logos in the world market although harmonization efforts have begun (Minkus-Mckenna, 2007). Thus, Muslim populations are making their presence felt socially and politically and are requesting for halal labeled food products (Riaz \& Chaudry, 2004).

The way of life for all Muslims regardless of where they live, are based on Islamic principles. For food, Islam decodes that food must be fit for human consumption in accordance with "halal" requirements of Syariah. However, how "halal" is assured requires the involvement of the country's regulations and regulating bodies under the jurisdiction of the country's law. Since many of the food producers in Malaysia comprise of SMEs, are such enterprises concerned about getting halal certification for their products? It is the objective of this paper to examine SMEs' perceptions of the halal certification process as anecdotal evidence from press reports appear to indicate that many SMEs are reluctant to apply for certification because the process is costly, takes a long time and imposes a burden to the business. Despite strict regulations by the Malaysian authorities on Halal Labeling, incidences of false labeling could mar the credibility of the Halal Label adopted by the relevant authority chiefly, JAKIM (Talib et al., 2010). As such this study will be able to help the policy makers and regulators in reviewing their policy besides taking some corrective actions to meet the worldwide demand on Halal food as required by the Muslim population. It also will be able to serve as a feedback to agencies tasked with oversight of food quality especially in the Asian region besides contributing to the body of knowledge and marketing strategy of SME entrepreneurs particularly who involved in food and beverage industry.

\section{Overview}

According to the Pew Research Center's Forum on Religion and Public Life (2009), the total number of Muslim population worldwide is estimated to be 1.57 billion out of an estimated total world population of 6.8 billion. Thus the Muslim population is growing rapidly with nearly one in four people in the world practicing Islam. Therefore, various marketing opportunities are available to meet the needs of Muslims worldwide especially in the halal food industry with the potential halal sector to contribute to the economy of a country. The Halal industry has seen considerable growth and development over the years fuelled by the escalation in awareness of Halal products among consumers and product manufacturers (Global Leader, 2008). With the global emphasis on food marketing, it is thus imperative that the food industry understands the requirements of the Muslim consumers if it wants to tap the Muslim market which represents $24 \%$ of the world's total population in 2005 (one man out of four) and this figure will attain 33\% in 2050 (One man out of three), and it could reach $37 \%$ in 2100 (One man out of 2.7). The size of the halal food market for Malaysia was estimated US\$8.2 billion in 2009 and US\$8.6 billion in 2010 (Chan, 2011).

Most of past researches concerning Halal food in Malaysia were mainly focused on consumers' behavior and not many have been done on the SMEs and Halal food certification. Some researches on the SMEs are like Marzuki, Hall, and Ballantine (2011) reported that most of the restaurant managers have high expectations toward halal certification as it signifies attributes such as trust, safety, and hygiene, thus Halal certification is therefore perceived by restaurant managers as an important aspect in the food service industry. Abdul et al. (2009) reported that based on their survey on 136 SME owners that there was a significant relationship between religion of the SME owners and Halal certification, however, in contrary there was no significant association 
between Halal certification and venturing internationally. They also reported that majority of their respondents agreed that Malaysia has the potential to lead the Halal certification and has the potential to be a Halal hub. However, the Government of Malaysia needs to improve on the monitoring mechanism on Halal certification to improve its compliance. Thus this paper provides a more in-depth study on this topic, particularly it ranks the respondents from various characteristics and their perceptions towards four categories of Halal Food Certification (HFC): HFC 1 (respondents' perceptions towards market share and market competitiveness); HFC 2 (their views on the government support and monitoring); HFC 3 (perceptions on information dissemination); and HFC 4 (their level of agreement/disagreement on the stringency and tediousness of the certification process).

Exploring the entrepreneurial actions towards enhancing their business will not be complete without considering the attitudes of their customers, whom indirectly affect the entrepreneurial business strategy.

Attitudes toward a product are not only determined by the consumers' motives and the consumption experience, but also by their perceptions of the product (Alvensleben, 1997; Jamal, 2003; Talib et al., 2010). Perception is most likely to be distorted. Subsequently, the perceived world and the real world do not correspond with each other and attitudes regarding the perceived properties of the product are linked to selected variables (Kotler \& Armstrong, 1993). The more positive or negative is a consumer's attitude towards a product, the more drawn the consumer is to the positive (or negative) properties of the brand-leading to a stabilization of the attitude towards the product (Kotler \& Armstrong, 1993). Santos and Fernandes (2008) emphasized that consumer trust is sensitive to perceptions of justice and the importance of trust of consumers in a company. Without a detailed understanding of buyer behavior and the purchasing process, marketing strategies are based on incomplete and often misleading data, hence the challenge is to generate the critical information on buying behavior directly from consumers. In the international food market, Malaysian Halal product exports are less than half of Thailand's while exports to the Middle East make up only $0.5 \%$ of total volume (Toh, 2009). Furthermore, unlike multinational corporations like the Nestle group, which has already carved a name for itself in the halal industry, many people in the international halal market are still not familiar with Malaysian's local halal companies since many of them are small- and medium-enterprises and this could be seen as an obstacle for them to penetrate the global market (Toh, 2009).

Given the obstacles surrounding the SMEs to venture into the international market, initiatives such as the Government Guarantee Scheme was introduced to assist in upgrading the SME's capabilities and capacities enabling them to export and produce as well as penetrating the global Halal market (Daganghalal.com, 2009). Besides, the Halal Industry Development Corporation (HDC) has implemented The Halal Anchor Company Program to facilitate the SME development by identifying, grooming, and developing an elite group of home-grown SMEs to penetrate the global Halal market and in the process serve as iconic role models and inspiration to other SMEs in the Halal related industries (Halal Industry Development Corporation, 2009).

\section{Market Competition}

According to mainstream economic theory, the notion of competition is associated with the absence of market power to change in price or product quality (Kirzner, 2000). Hence a competitive market is one in which no firm possesses market power. Thus competition is seen as the antithesis of monopoly. To understand market competition and rivalry among the firms, ones need to be exposed or have knowledge on the competitive business environment. Thus in an indirect way one can conclude that by attending entrepreneurship 
course or exposed to a higher academic institution, based on the entrepreneurs' past experiences like attending strategic management and marketing literature courses (which fall under entrepreneurship program) could possibly enable them to understand competition from a cognitive psychology, marketing and strategic management perspective. Hence it served as a competitive advantage for these entrepreneurs when compared with those who have not been exposed before. As suggested by Kemp et al. (2004), an important field of competition in strategic management is concentrating on mapping the competitive environment. The marketing and strategic management stream of literature on competition pays more attention to the process behind competitive strategy and the decision making process of competitive action, most of the time at firm level of analysis. Among business strategy and marketing scholars there is common ground that an important role is played in competition by key decision makers who monitor rival organizations and formulate strategies to achieve competitive success (e.g., Porter, 1980). According to Porac and Thomas (1990) it is because that this key role played by decision makers in an organization's response to rivalry, that "inquiry is necessary about the social psychological factors influencing how decision makers frame competitive environments and understand the nature of competitive perceptions” (p. 224). The same goes to the SMEs involved in Halal food. Based on the information gathered and events observed, characteristics of the different firms in the firm's environment, the firm's business definition and strategy and other variables, decision-makers form their competitive map. Similarly, Kemp et al. (2004) argued that in cognitive psychology there is also a well-known information-processing framework that consists of the following steps: (1) observing information or events; (2) the interpretation thereof; and (3) the reaction according to this interpretation. This framework is also used in strategic management and marketing to capture the perception of competition among the firms involved in Halal food.

In relation to this study, the government's role is to ensure that firms comply with the halal certification by providing a proper monitoring mechanism because the government agency such as Jabatan Kemajuan Islam Malaysia (JAKIM) or state Department of Religious Affairs have been entrusted with issuing halal certification.

\section{Methodology}

A set of structured questionnaires were distributed among SMEs entrepreneurs who participated in the Malaysian International Halal Showcase (MIHAS) 2011 from 26-28 February based in Penang and from 6-9 April 2011 based in Kuala Lumpur. MIHAS is an event organized annually by the Malaysian Government to help SMEs throughout Malaysia to showcase their products and link with potential overseas partners. In the process, SME Corp has identified businesses which are SMEs involved in the Food and Beverage businesses, hence this event provides a ready made sample of Food and Beverage businesses in the SME Category in Malaysia.

The questionnaire was divided into two sections. The first section deals with respondents' demographic data such as gender, age, marital status, academic background, entrepreneurship course, ventured internationally, and certification for the product(s). The second section consists of 18 questions:

- Six questions eliciting their perceptions towards the market share and market competitiveness (denoted as HFC 1);

- Five questions on their views on the government support and monitoring (denoted as HFC 2);

- Five questions eliciting their perceptions on information dissemination on halal hub (denoted as HFC 3);

- Two questions posed to elicit their levels of agreement/disagreement on the stringency and tediousness of 
the certification process (denoted as HFC 4).

Respondents were asked to fill in the questionnaire indicating their level of agreement or disagreement in the Second Section using a five point Likert Scale where 1 indicates strongly disagree and the other end 5 indicates strongly agree.

A mean score for each of the HFC was computed, which were later used to test for their significance (two-tailed $t$-test) against the respondents' characteristics. The characteristics used were as follows:

- Either has undertaken entrepreneurship course or otherwise;

- Has ventured internationally or otherwise;

- Has certification for product(s) or otherwise;

- Academic background-Has at least a degree or otherwise.

As this is an exploratory study, this study seeks to test the following propositions:

- Proposition 1-There is a significant relationship between those entrepreneurs who have attended entrepreneurship course compared with those who did not attend;

- Proposition 2-There is a significant relationship between the SME entrepreneurs who have ventured internationally compared with those who did not;

- Proposition 3-There is a significant relationship between the SME entrepreneurs who have halal certified product(s) versus who did not have;

- Proposition 4-There is a significant relationship between the SME entrepreneurs who have at least a bachelor or degree compared with those without degree.

Data were analyzed using an independent $t$-test using Statistical Package for Social Sciences (SPSS). This statistical test was done to compare the mean of an independent variable under study in two sets of data and search whether there exist any significantly different from these two mean values due to the treatment (under dependent variables) and not any other factors at 0.1 and 0.05 significant levels. Two-tailed $t$-test was chosen because of is non-directional test.

\section{Results}

A total of 108 usable questionnaires were collected from the exhibitors at the MIHAS 2011 exhibition. The Cronbach Alpha result gives 0.91 (see Table 1) and factor analysis, the Kaiser-Meyer-Olkin measure of sampling adequacy gives 0.840, exceeding the recommended value of 0.6 (Ho, 2006) and the Bartlett's test of Sphericity (Bartlett, 1954) gives approximate value of Chi-Square of 1156.909 (df 153) and Significant value is 0.000. Hence the Cronbach and factor analysis results confirmed that the set of questionnaire is both valid and reliable.

Table 1

Reliability Test

$\left.\begin{array}{lll}\hline \text { No. of questions } & \text { HFC } & \text { Value of cronbach alpha } \\ \hline 6 & \text { HFC 1 } & 0.90 \\ 5 & \text { HFC 2 } & 0.89 \\ 5 & \text { HFC 3 } & 0.88 \\ 2 & \text { HFC 4 } & 0.69\end{array}\right\} 0.91$




\section{Part 1-General Results}

Table 2 shows overall summary of the descriptive statistical analysis on the HFC. Generally all of the questions on HFC are distributed normally as depicted in this table. Based on the five-point Likert Scale used, the minimum for all HFCs rating was 1 and a maximum of 5.00 and this gives a range of 4 . This table reflects that most of respondents agreed that Halal Certification promotes satisfaction, confidence and trust with a mean score of 4.27. They also agreed that Halal Certification is important to increase market share (mean score is 4.25) and market competitiveness (mean score is 4.19). However, there were some problems in the dissemination of information on halal hub such as the contents of information were insufficient (mean score is 3.01), was not up to date (mean score is 3.05 ) and was not published in regularly accessed media (mean score is 3.16).

Table 2

General Descriptive Statistical Analysis

\begin{tabular}{|c|c|c|c|c|c|c|c|c|}
\hline Questions number & Mean & Median & Std. Dev. & Minimum & Maximum & Range & Kurtosis & Skewness \\
\hline $\begin{array}{l}1 . \quad \text { Awareness } \\
\text { involved (HFC 1) }\end{array}$ & 3.95 & 4.00 & 1.122 & 1 & 5 & 4 & 0.611 & -1.160 \\
\hline 2. Tediousness (HFC 4) & 3.64 & 4.00 & 0.901 & 1 & 5 & 4 & -0.157 & -0.465 \\
\hline 3. Stringentness (HFC 4) & 3.91 & 4.00 & 0.952 & 1 & 5 & 4 & 0.445 & -0.804 \\
\hline $\begin{array}{l}\text { 4. Increase market share } \\
\text { (HFC 1) }\end{array}$ & 4.25 & 4.00 & 0.968 & 1 & 5 & 4 & 3.185 & -1.721 \\
\hline $\begin{array}{l}5 . \quad \text { Increase market } \\
\text { competitiveness (HFC 1) }\end{array}$ & 4.19 & 4.00 & 0.919 & 1 & 5 & 4 & 2.699 & -1.484 \\
\hline $\begin{array}{l}\text { 6. Customers very particular } \\
\text { HFC (HFC 1) }\end{array}$ & 3.94 & 4.00 & 1.026 & 1 & 5 & 4 & 0.937 & -1.086 \\
\hline $\begin{array}{l}\text { 7. HFC promotes satisfaction, } \\
\text { confident \& trust (HFC 1) }\end{array}$ & 4.27 & 4.00 & 0.953 & 1 & 5 & 4 & 3.448 & -1.753 \\
\hline $\begin{array}{l}\text { 8. Potential to be halal hub } \\
\text { (HFC 1) }\end{array}$ & 4.08 & 4.00 & 0.855 & 1 & 5 & 4 & 2.889 & -1.441 \\
\hline $\begin{array}{l}\text { 9. Regulatory framework is } \\
\text { sufficient (HFC 2) }\end{array}$ & 3.45 & 4.00 & 1.054 & 1 & 5 & 4 & -0.347 & -0.609 \\
\hline $\begin{array}{l}\text { 10. Proper monitoring } \\
\text { mechanism (HFC 2) }\end{array}$ & 3.36 & 4.00 & 1.148 & 1 & 5 & 4 & -0.754 & -0.446 \\
\hline $\begin{array}{l}11 . \quad \text { Govt. proactive } \\
\text { enforcing HFC (HFC 2) }\end{array}$ & 3.36 & 4.00 & 1.156 & 1 & 5 & 4 & -0.589 & -0.561 \\
\hline $\begin{array}{l}\text { 12. Transportation system is } \\
\text { effective (HFC 2) }\end{array}$ & 3.29 & 4.00 & 1.120 & 1 & 5 & 4 & -0.469 & -0.591 \\
\hline $\begin{array}{l}\text { 13. Facilities for research } \\
\text { centers (HFC 2) }\end{array}$ & 3.32 & 4.00 & 1.101 & 1 & 5 & 4 & -0.462 & -0.505 \\
\hline $\begin{array}{l}\text { 14. Content of information is } \\
\text { sufficient (HFC } 3 \text { ) }\end{array}$ & 3.01 & 3.00 & 1.123 & 1 & 5 & 4 & -0.974 & -0.220 \\
\hline $\begin{array}{l}\text { 15. Content of information is } \\
\text { up to date (HFC } 3 \text { ) }\end{array}$ & 3.05 & 3.00 & 1.071 & 1 & 5 & 4 & -0.781 & -0.233 \\
\hline $\begin{array}{l}\text { 16. Content of information is } \\
\text { published regularly (HFC } 3 \text { ) }\end{array}$ & 3.16 & 3.00 & 1.069 & 1 & 5 & 4 & -0.687 & -0.227 \\
\hline $\begin{array}{l}\text { 17. Halal hub information is } \\
\text { relevant (HFC 3) }\end{array}$ & 3.51 & 4.00 & 0.891 & 1 & 5 & 4 & 0.843 & -1.118 \\
\hline $\begin{array}{l}\text { 18. Sufficient websites on } \\
\text { halal products (HFC } 3 \text { ) }\end{array}$ & 3.29 & 4.00 & 0.977 & 1 & 5 & 4 & -0.598 & -0.546 \\
\hline
\end{tabular}

Among these four HFCs, based on the average mean score (see Table 3), HFC 1 (market share and competitiveness) scored the highest (average mean score is 4.113). This shows that most of respondents agreed that Halal Certification enables them to increase their market share and market competitiveness. However, most of them agreed that Halal Certification process was tedious and stringent (HFC 4 with average mean score of 
3.775 - second top of the list). It seems that they were not satisfied with the current Malaysian government support and monitoring (HFC 2), only being third in the list (average mean score is 3.356); and finally there were problems with information dissemination on halal hub (HFC 3) being the last in the list (average mean score is 3.204).

Table 3

Descriptive Statistics for Each of the HFC

\begin{tabular}{llll}
\hline HFC No. & Average mean & Average Std. Dev. & No. of items \\
\hline HFC 1 & 4.113 & 0.974 & 6 \\
HFC 2 & 3.356 & 1.116 & 5 \\
HFC 3 & 3.204 & 1.026 & 5 \\
HFC 4 & 3.775 & 0.9265 & 2 \\
\hline
\end{tabular}

\section{Part 2-Specific Results}

Principle Components Analysis (PCA) revealed the presence of four components with Eigen values exceeding 1 and Table 4 presents the total and cumulative variance for each of the HFC. HFC 1 contributes the most as it accounts for the largest variance (40.9\%) among the HFCs, followed by HFC 2 and so on.

Table 4

Principal Components Analysis Statistics

\begin{tabular}{lccc}
\hline \multirow{2}{*}{ Component } & \multicolumn{3}{c}{ Initial eigenvalues } \\
\cline { 2 - 4 } & Total & \% of variance & Cumulative \% \\
\hline HFC 1 & 7.357 & 40.873 & 40.873 \\
HFC 2 & 2.542 & 14.122 & 54.995 \\
HFC 3 & 8.440 & 63.435 \\
HFC 4 & 1.519 & 6.444 & 69.879 \\
\hline
\end{tabular}

Tables 5 and 6 depict the results of the study. Table 6 shows that respondents who have undertaken entrepreneurship course compared with those who have not taken the course produces significant results for all the HFCs (HFC 1 to HFC 4) at least at 90\% confidence level, thus it supports that there is a significant relationship between entrepreneurs who have undertaken entrepreneurship course and HFC1 to HFC 4.

Table 5

Profile of Respondents

\begin{tabular}{|c|c|c|c|}
\hline No. & Characteristics & Total No. & Percentage \\
\hline \multirow[t]{3}{*}{1.} & Undertaken entrepreneurship course & & \\
\hline & Yes & 55 & 50.9 \\
\hline & No & 53 & 49.1 \\
\hline \multirow[t]{3}{*}{2.} & Ventured internationally & & \\
\hline & Yes & 42 & 38.9 \\
\hline & No & 66 & 62.1 \\
\hline \multirow[t]{3}{*}{3.} & Has halal certified product(s) & & \\
\hline & Yes & 74 & 68.5 \\
\hline & No & 34 & 31.5 \\
\hline \multirow[t]{3}{*}{4.} & Academics background & & \\
\hline & Degree holder & 55 & 50.9 \\
\hline & Non-degree holder & 53 & 49.1 \\
\hline
\end{tabular}

As for academic background of respondents, it seems that there is a significant relationship between academic background of respondents with HFC 1 and HFC 3 at 95\% confidence level and with HFC 4 at 90\% 
confidence level. However, there is no significant relationship between academic backgrounds of respondents with HFC 2.

Table 6

HFC Versus Entrepreneurs' Characteristics

\begin{tabular}{|c|c|c|c|}
\hline HFC & Description & Mean & Value \\
\hline \multirow[t]{13}{*}{ HFC 1} & Perceptions towards market share and market competitiveness & & \\
\hline & (1) Entrepreneurship course & & \\
\hline & a. Yes & 4.2516 & \multirow{2}{*}{$0.078^{*}$} \\
\hline & b. No & 3.9788 & \\
\hline & (2) Ventured internationally & & \\
\hline & a. Yes & 4.1151 & \multirow{2}{*}{0.951} \\
\hline & b. No & 4.1051 & \\
\hline & (3) Halal certificate for product(s) & & \multirow{3}{*}{$0.025^{* *}$} \\
\hline & a. Yes & 4.2297 & \\
\hline & b. No & 3.3578 & \\
\hline & (4) Academic background & & \multirow{3}{*}{$0.028^{* *}$} \\
\hline & a. Degree level & 4.2788 & \\
\hline & b. Non-degree level & 3.9403 & \\
\hline \multirow[t]{13}{*}{ HFC 2} & \multicolumn{3}{|l|}{ Views on the government support and monitoring } \\
\hline & (1) Entrepreneurship course & & \\
\hline & a. Yes & 3.1811 & \multirow[t]{2}{*}{$0.052^{*}$} \\
\hline & b. No & 3.5273 & \\
\hline & (2) Ventured internationally & & \multirow{3}{*}{$0.027^{* *}$} \\
\hline & a. Yes & 3.1048 & \\
\hline & b. No & 3.5108 & \\
\hline & (3) Halal certificate for product(s) & & \multirow{3}{*}{0.471} \\
\hline & a. Yes & 3.3135 & \\
\hline & b. No & 3.4529 & \\
\hline & (4) Academic background & & \multirow{3}{*}{0.465} \\
\hline & a. Degree level & 3.9057 & \\
\hline & b. Non-degree level & 3.6455 & \\
\hline \multirow[t]{13}{*}{ HFC 3} & Perceptions on information dissemination & & \multirow{4}{*}{$0.005^{* *}$} \\
\hline & (1) Entrepreneurship course & & \\
\hline & a. Yes & 2.9698 & \\
\hline & b. No & 3.4255 & \\
\hline & Ventured internationally & & \multirow{3}{*}{0.105} \\
\hline & a. Yes & 3.0381 & \\
\hline & b. No & 3.3108 & \\
\hline & (3) Halal certificate for product(s) & & \multirow{3}{*}{0.474} \\
\hline & a. Yes & 3.1622 & \\
\hline & b. No & 3.2882 & \\
\hline & Academic background & & \multirow{3}{*}{$0.030^{* *}$} \\
\hline & a. Degree level & 3.3745 & \\
\hline & b. Non-degree level & 3.0226 & \\
\hline
\end{tabular}

HFC 4 Level of agreement/disagreement on the stringentness \& tediousness of the certification process

(1) Entrepreneurship course
a. Yes
b. No
(2) Ventured internationally
a. Yes
b. No
(3) Halal certificate for product(s)
a. Yes
3.6757
b. No
3.9853
$0.062^{*}$
(4) Academic background
a. Degree level
b. Non-degree level
3.6455
3.9057
$0.092^{*}$

Note. ${ }^{*}$ Significant at $10 \%$ level; ${ }^{* *}$ Significant at $5 \%$ level. 
In relation to venturing internationally, there is a significant relationship between entrepreneurs who have ventured internationally with HFC 2 and HFC 4 at 95\% confidence level in contrary to HFC 1 and HFC 3 that indicate no significant relationship.

Finally those SME entrepreneurs who managed to have their product(s) halal certified gave a significant result for HFC 4 at 0.1 significant level. On the other hand, there is no significant relationship between the SME entrepreneurs who managed to have their product(s) halal certified compared with those who did not have in relation to HFC 1, HFC 2, and HFC 3.

\section{Discussion}

Most of respondents agreed that Halal Certification able to promote satisfaction, confidence and trust among consumers. Living in a multicultural society as in Malaysia with different religious background, hence being a Muslim, one needs assurance that food to be selected and consumed meets the Islamic tenet of "Halal" or fit for consumption because food was prepared by third party. Since Halal is a credence quality attribute, thus it was merely based on trusted information, such as halal certified by JAKIM or by the state Department of Religious Affairs could enhance their perceptions that the food taken is halal. Similarly, they also understand that by having their products halal certified could boost their market share and market competitiveness. However, their perceptions towards information dissemination on halal hub was low and need to be taken into consideration by JAKIM and state Department of Religious Affairs in promoting halal hub amongst SMEs like the sufficiency of its contents, up to date information and published regularly in accessed media.

Besides information dissemination, JAKIM also needs to improve on the certification process. They could educate these SME entrepreneurs by giving proper trainings or seminars on halal certification process before registering their products for certification so that they understand the process thoroughly. The Malaysian government also needs to improve on its support and monitoring if it wants to be a champion in the halal food product industry.

In relation to the propositions, perceptions of respondents who have undertaken entrepreneurship course compared with those who have not taken the course show significance differences for all the HFCs (HFC 1 to HFC 4). The entrepreneurship course that they have undertaken could possibly enabled them to foresee the opportunities to increase their market share and competitiveness through Halal Certification (HFC 1). By having their product(s) Halal Certified could instill customers' confidence and trust and also presents one of their strategies to be competitive in the market place as suggested by Kemp et al. (2004). Through their basic knowledge in entrepreneurship that they have studied also could affect their expectation from the government to provide more support and monitoring compared with those who have not studied entrepreneurship (HFC 2). They also expect the information dissemination on Halal hub like the contents, different types of media publication and the relevance still need to be improved compared with those who have not taken entrepreneurship course before (HFC 3). However, entrepreneurs who have undertaken entrepreneurship course before found that the certification process was not that stringent or tedious compared with their counterparts. This could be due to their exposure in the course (HFC 4).

As for the academic background of respondents, it shows that HFC 1, HFC 3, and HFC 4 to be significant. This could be explained that educated entrepreneurs were able to see the trend of customers' needs and wants compared with those non-educated entrepreneurs (HFC1). They also expect more from the information dissemination compared with those uneducated ones (HFC 3). They also might find that the process of getting 
Halal Certification was not that tedious and stringent compared with those who were not educated could be possibly due to their knowledge and exposure in the university (HFC 4).

As for those who have ventured internationally compared with those who have not, there are significance results for HFC 2 and HFC 4. Possibly this is due to their tendency to compare with the government of other countries and foresee that the government of Malaysia could do more to support and monitor local entrepreneurs compared with those who have not being exposed to international market. Similarly, they might find that the process of Halal Certification was not stringent and tedious compared to their counterparts.

Those who have Certified Halal products gave significance results for HFC 1 and HFC 4. This could be explained that they foresee by having Halal product Certification will enable them to boost their market share hence expanding their businesses through customers' confidence and trust (HFC 1). Since they have undergone the Halal Certification process, they might find that the process of getting Halal Certification was not that tedious and stringent compared with those who did not have Halal Certified products.

\section{Conclusions}

This paper reports on the relationship between four characteristics of SMEs (involved in halal food) viz. attended entrepreneurship course, managed to venture in the international market, able to have their product(s) Halal Certified and their academic background in relation to their perceptions towards market share and market competitiveness, their views on government support and monitoring, their perceptions on halal hub information dissemination and their level of agreement on the stringency and tediousness of the Halal Certification process. Results show that respondents who have undertaken entrepreneurship course compared with those who have not taken the course produced significant results for all the HFCs tested. There are significant differences between those with and without degree for HFC 1, HFC 3, and HFC 4. In relation to venturing internationally, the results show that there are significant differences between those who managed to venture internationally compared with those who did not with HFC 2 and HFC 4. Finally having halal certified product(s) is significant only for HFC 4.

The study suggests that the government/policy makers need to take some corrective actions in order to enhance Halal Food Certification process in Malaysia. Similarly it also needs to improve on the Halal hub information dissemination if it wants to be a champion in this industry. Future studies should consider entrepreneurs from other jurisdictions as to how they perceive the Halal Certification process in their country to discern if cultural factors could affect such perceptions. Future studies can also consider problems experienced by SMEs according to different food sectors.

\section{References}

Abdul, M., Ismail, H., Hashim, H., \& Johari, J. (2009). SMEs and halal certification. China-USA Business Review, 8(4), $22-29$.

Alvensleben, R. V. (1997). Consumer attitudes and behaviour on the meat market in Germany. In R. V. Alvensleben, S. V. Cramon-Taubadel, A. Rôhr, \& K. Schleyerbach (Eds.), Problems of meat marketing, seven essays. Arbeitsbericht Nr. 2. Lehrstuhl für Agrarmarketing, Universităt Kiel.

Bartlett, M. S. (1954). A note on multiplying factors for various chi-squared approximations. Journal of the Royal Statistical Society, 16, 296-298.

Chan, C. T. (2011). Malaysia: SME's in the halal sector. Retrieved September 6th, 2011, from http://halalfocus.net/2011/03/29/malaysia-smes-in-the-halal-sector/

Daganghalal.com. (2009). SMEs urged to use guarantee schemes to penetrate halal market. Retrieved November 16th, 2009, from http://www.daganghalal.com 
Darby, M., \& Karni, E. (1973). Free competition and the optimal amount of fraud. Journal of Law and Economics, 16, 67-88.

FMM-MATRADE industry directory. (2010). Food \& Beverage (4th ed.). Federation of Malaysian Manufacturers (FMM) in collaboration with Malaysia External Trade Development Corporation (MATRADE), Kuala Lumpur, Malaysia.

Global Leader. (2008). World population prospects the Islamic bombs. Retrieved November 17th, 2009, from http://www.freeworldacademy.com/globalleader/population.htm

Grunert, K. G. (2005). Food quality and safety: Consumer perception and demand. European Review of Agricultural Economics, 32, 369-391.

Halal Industry Development Corporation. (2009). Halal anchor company. Retrieved November 12th, 2009, from http://www.hdcglobal.com/portal/indices/index_171.html

Ho, R. (2006). Handbook of univariate and multivariate data analysis and interpretation with SPSS. Rockhampton: Chapman \& Hall/CRC.

Jamal, A. (2003). Marketing in a multicultural world the interplay of marketing, ethnicity and consumption. European Journal of Marketing, 37(11/12), 1599-1620.

Kemp, R. G. M., \& Hanemaaijer, J. J. (2004). Perception of competition: A measurement of competition from the perspective of the firm. Research Report/Zoetermeer: EIM Business \& Policy Research, H200406, Scientific analysis of entrepreneurship and SMEs.

Kirzner, I. M. (1982). Competition, regulation, and the market process an Austrian perspective. Cato Institute Policy No. 18.

Kirzner, I. M. (2000). The irresistible force of market competition. Retrieved June 21, 2011, from http://www.thefreemanonline.org

Kotler, P., \& Armstrong, G. (1993). Marketing: An introduction (3rd ed.). New York, N.Y.: Prentice Hall.

Marzuki, S. Z. S., Hall, C. M., \& Ballantine, P. W. (2011). Restaurant manager expectations toward halal certification in Malaysia. Journal of Foodservice Business Research, 15(2), 195-214.

Minkus-McKenna, D. (2007). The pursuit of halal. Progressive Grocer, 86(17), 42.

Pew Research Center's Forum on Religion and Public Life. (2009). Mapping the global Muslim population: A report on the size and distribution of the world's Muslim population. Retrieved November 17th, 2009, from http://pewforum.org/docs/DocID=450

Porac, J. F., \& Thomas, H. (1990). Taxomonic mental models in competitors definition. Academy of Management Review, 15(2), 224-240.

Porter, M. E. (1980). Concurrentiestrategie: Analysemethoden voor bedrijfstakken \& industriële concurrentie. New York: The Free Press.

Riaz, M. N., \& Chaudry, M. M. (2004). The value of halal food production. Extrusion Technology Program, Texas A\&M University System.

Santos, C. P. D., \& Fernandes, D. V. D. H. (2008). Antecedents and consequences of consumer trust in the context of service recovery. Brazillian Administration Review, 5(3), 225-244.

Talib, Z., Zailani, S., \& Zainuddin, Y. (2010). Conceptualizations on the dimensions for halal orientation for food manufacturers: A study in the context of Malaysia. Pakistan Journal of Social Sciences, 7(2), 56-61.

Thut, C.C., \& Chang, K. (2010). Time to get down to work. Malaysia SME Bulletin, July 3-July 16.

Toh, L. H. (2009). Straight talk: Tapping the huge halal business. Retrieved November 17th, 2009, from http://www.bizedge.com/commentary/155833-straight-talk-tapping-the-huge-halal-business.html 